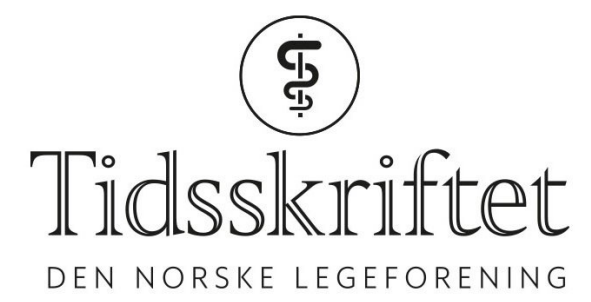

\title{
Anbud på hivlegemidler er ikke til pasientens beste
}

KOMMENTAR

\section{LEIF-OVE HANSEN}

E-post: leif-ove@hivnorge.no Leif-Ove Hansen er styreleder i HivNorge og brukerrepresentant i spesialistgruppen hivlegemidler. Ingen oppgitte interessekonflikter.

Det er med stor glede jeg leser at flere infeksjonsleger nå sier klart fra hva de synes om anbud på hivlegemidler. Fra pasientperspektivet er dette anbudet med på å sette hivbehandlingen i Norge i en nedadgående spiral, der prinsippet om best mulig behandling blir satt til side. Det har vært et ensidig fokus på pris i denne anbudsprosessen.

Samtidig er det å likestille alle hivbehandlinger som likeverdige så lenge de holder virusnivået nede, men det blir som å sammenligne epler og appelsiner. Medisinbytter for pasienter med kroniske sykdommer på livslang behandling som kun er begrunnet ut fra $\emptyset$ konomi er uforståelig, og enda verre når det legges opp til at anbud skal utlyses hvert eller annethvert år. Utgangspunktet i dag er at hivpositive pasienter er på en vellykket behandling uten bivirkninger. Nå skal alle spørres om å bytte til billigere medisiner som kan forårsake bivirkninger og som uansett vil kreve ekstra oppfølging. Vi som pasienter skal dermed bruke egen helse, tid og ressurser som innsats for å spare penger slik at det blir mer til annen behandling. At overføringene alt er kuttet i statsbudsjettet og at det dermed ikke tilfaller noe mer til helse er visst ikke relevant. Er det dette Stortingets ønske rundt anbud?

Som brukerrepresentant med observatørstatus i spesialistgruppen som lagde anbudet, kjenner jeg igjen mange av de innvendingene som Trøseid og hans kollegaer nevner i sin debattartikkel. Det at én-pillebehandling ikke tilegnes noen egenverdi av infeksjonslegene i spesialistgruppen var for meg underlig. De samme legene har i over 10 år fortalt meg og andre pasienter hvor flott én-pillebehandlingene er og at vi burde bruke dem. Det har også for mange pasienter blitt vanskelig å nå ha full tillitt til legene, når spørsmålet om bytte ikke har som mål å være best mulig behandling, men for å spare penger.

Jeg er helt enig i at bruken av anbud må stoppes. Det må finnes bedre modeller for å ivareta god hivbehandling, og samtidig få ned kostanden. Det var for eksempel fullt mulig å bytte til generiske legemidler innenfor blåreseptordningen, da hadde man sluppet å bruke millioner på anbud. Samtidig hadde man latt infeksjonslegen og pasienten velge den behandlingen som var best for pasienten. Man må også sørge for at nye hivbehandlinger blir tilgengelig for pasienter og ikke stoppes av beslutningsforum på grunn av pris. Dette vil på sikt gjøre Norge til et usikkert marked for legemiddelfirma å selge nye legemidler.

Det er et betimelig å stille seg spørsmålet hvor mye en skal spare? Skal vi hivpositive ofre vår 
helse i alderdommen for innsparinger på kort sikt? Vi pasienter er igjen de som blir skadelidende, når Helseforetakene skal spare penger på legemidler som holder oss friske, smittefri og i live. Jeg håper legene i spesialistgruppa for anbud på hivlegemidler setter en stopper for nye anbud. Jeg kan ikke forstå hvordan de faglig kan forsvare en ny runde.

Publisert: 28. januar 2019. Tidsskr Nor Legeforen. DOI:10.4045/tidsskr.19.0015

(C) Tidsskrift for Den norske legeforening 2020. Lastet ned fra tidsskriftet.no 